\title{
Koneksi Matematis Siswa pada Tugas Matematis Berbasis Hasil Pertanian: Konteks, Konsep, dan Prosedur Matematis
}

\author{
Ai Tusi Fatimah* \\ Program Studi Pendidikan Matematika, Universitas Galuh \\ *aitusifatimah@unigal.ac.id
}

\begin{abstract}
Abstrak
Koneksi matematis merupakan kemampuan yang penting dimiliki siswa Sekolah Menengah Kejuruan (SMK) dalam menyelesaikan masalah-masalah sesuai dengan bidang keahliannya. Pertanian merupakan salah satu bidang keahlian yang banyak memerlukan kemampuan koneksi matematis dalam menyelesaikan berbagai masalahnya. Peningkatan kemampuan koneksi matematis siswa dapat difasilitasi oleh guru dengan mengonstruksi tugas matematis sesuai dengan konteks bidang pertanian. Penelitian kualitatif dengan metode studi kasus ini mendeskripsikan konstruksi tugas matematis berbasis hasil pertanian dan kemampuan koneksi matematis siswa dalam menyelesaikan tugas tersebut. Konstruksi tugas matematis dilakukan dengan mengintegrasikan konteks-konteks hasil pertanian dan konsep-konsep matematika. Tugas matematis tersebut digunakan pada pembelajaran matematika siswa SMK Keahlian Agribisnis Pengolahan Hasil Pertanian Kelas X. Pengambilan data kemampuan koneksi matematis siswa dilakukan melaui tes, observasi, dan wawancara yang terfokus pada kemampuankoneksi konteks denga konsep matematis, koneksi antar konsep matematis, dan koneksi prosedur matematis. Hasil analisis data menunjukkan bahwa kemampuan koneksi matematis banyak terkendala pada kemampuan koneksi antar konsep matematis. Diperlukan peningkatan kemampuan koneksi matematis siswa dengan melakukan konstruksi tugas matematis yang memiliki keragaman konsep matematika.
\end{abstract}

Kata kunci: hasil pertanian, koneksi matematis, tugas matematis

\begin{abstract}
The mathematical connection is a crucial ability possessed by vocational high school students in solving problems by their field of expertise. Agriculture is a field of expertise that requires a lot of mathematical connection skills to solve various problems. Increasing the ability of students' mathematical connections can be facilitated by the teacher by constructing mathematical tasks in the agricultural sector. This qualitative research using the case study method describes the construction of mathematical tasks based on agricultural products and the mathematical connection ability of students in solving the task. Mathematical task construction is carried out by integrating agricultural product contexts and mathematical concepts. The mathematical task was used in Grade $\mathrm{X}$ Agribusiness Expertise students of Agricultural Product Processing. Data retrieval of students' mathematical connection abilities was carried out through tests, observation results, answer sheets, and interviews that focused on connecting contexts with mathematical concepts, connections between mathematical concepts, and connections to mathematical procedures. The results of the student data analysis showed that the ability of mathematical connections was hampered by the ability of the connection between mathematical concepts. It is necessary to increase student's mathematical connections by constructing mathematical tasks with various mathematical concepts.
\end{abstract}

Keywords: agricultural products, mathematical connection, mathematical tasks

Received: February 14, 2021 / Accepted: March 24, 2021 / Published Online: July 13, 2021 


\section{Pendahuluan}

Pendidikan matematika di sekolah kejuruan memiliki tujuan khusus yang membedakannya dengan sekolah umum. Matematika di sekolah kejuruan merupakan matematika kejuruan yang memiliki tujuan untuk mempersiapkan siswa menghadapi dunia kerja (Bakker, 2014; FitzSimons, 2014). Pendidikan matematika kejuruan memiliki karakteristik yang khas, yaitu tidak terlihat, bersifat rutin, dan dapat berkontribusi dalam pemecahan masalah yang rumit di tempat kerja (FitzSimons \& Björklund Boistrup, 2017) serta bersifat black box (Williams \& Wake, 2007). Dengan demikian, jelaslah bahwa pendidikan matematika yang terkoneksi dengan bidang keahlian siswa diperlukan untuk mempersiapkan siswa bekerja sesuai dengan keahliannya.

Guru matematika SMK senantiasa harus berusaha mengoneksikan matematika pada konteks-konteks kejuruan sesuai dengan bidang keahlian siswa. Koneksi matematis ini menjalinkan aktivitas matematika dan unsur-unsur kontekstual. Kegiatan ini bukanlah hal yang mudah untuk dilakukan karena guru harus memiliki kemampuan yang bersifat hybrid, yaitu memahami konteks matematika sekaligus konteks kejuruan (Bakker, 2014). Matematika yang digunakan di tempat kerja juga bersifat praktis. Hasil analisis menunjukkan bahwa filosofi praktik matematika bersifat multidisiplin (Hamami et al., 2020). Oleh karena itu, guru matematika hendaknya memahami struktur matematika terlebih dahulu untuk menerapkannya dalam pengajaran matematika. Kerangka kerja untuk mengkategorikan struktur matematika yaitu: koneksi ke pembelajaran lain, mengenali pola, mengidentifikasi persamaan dan perbedaan, serta generalisasi dan penalaran (Gronow et al., 2020). Untuk mewujudkannya, diperlukan rekontekstualisasi dalam mengoneksikan matematika pada suatu konteks.

Rekontekstualisasi merupakan suatu alat untuk melakukan koneksi (Llinares, 2020). Rekontekstualisasi merupakan transformasi berbagai pengetahuan dan pengalaman pribadi guru ke dalam pengajaran untuk menumbuhkan teori pembelajaran (Lin et al., 2018) sehingga menciptakan pembelajaran yang efektif untuk siswa dari berbagai latar belakang (KinserTraut \& Turner, 2020). Teori rekontekstualisasi diusung oleh Bernstein (2000), yaitu prinsipprinsip yang dasar dari pedagogisasi pengetahuan dan transformasinya dalam konteks yang berbeda. Misalnya mengubah wacana praktik menjadi wacana sekolah. Rekontekstualisasi dalam penelitian ini ditujukan untuk mentransformasikan konteks-konteks suatu bidang keahlian sebagai wacana dalam tugas matematis yang dirancang untuk siswa SMK.

Melalui tugas matematis, guru matematika dapat menyajikan konteks pada konsep matematika yang bersifat teoretis dalam berbagai strategi, teknik, dan artefak (FitzSimons \& Björklund Boistrup, 2017). Tugas matematis adalah salah satu artefak sebagai alat interaksi 
kognitif dan sosial yang terjalin di antara guru, siswa, dan matematika (Johnson et al., 2017). Tugas matematis dalam penelitian ini berusaha menjembatani matematika yang bersifat formal dengan matematika yang digunakan dalam praktik pengolahan hasil pertanian. Desain tugas ini diharapkan dapat mendukung siswa memiliki pemahaman matematis dalam menyelesaikan masalah sesuai dengan bidang keahliannya.

Bagi siswa, keberadaan konteks dalam suatu wacana memiliki peran dalam proses berpikir matematis siswa. Konteks masalah sangat mempengaruhi proses berpikir siswa (Chang et al., 2020). Struktur konteks yang disajikan secara berbeda-beda kepada siswa dapat meningkatkan pemikiran non-rutin siswa (Pongsakdi et al., 2020). Bagi siswa SMK keberadaan konteks berperan dalam mengembangkan keterampilan matematika di tempat kerja (Lacroix, 2014). Secara khusus, hasil penelitian pada siswa SMK bidang agribisnis menunjukkan bahwa konteks pertanian mempengaruhi kemampuan pemahaman dan penalaran matematis siswa dalam penyelesaian tugas (Fatimah \& Prabawanto, 2020). Pengetahuan konteks petanian yang dimiliki oleh siswa dapat mendukung pemahaman matematis siswa (Fatimah et al., 2020) serta penalaran kreatif matematis siswa (Fatimah et al., 2019). Selain itu, Konteks-konteks pertanian dapat digunakan untuk mengidentifikasi kemampuan number sense siswa (Fatimah \& Wahyudin, 2020). Penelitian-penelitian tersebut menunjukkan bahwa pentingnya merancang tugas matematis dengan mengoneksikan kontekskonteks suatu bidang keahlian untuk memfasilitasi interaksi kognitif siswa di kelas matematika.

Dalam bidang agribisnis, banyak konteks-konteks yang melibatkan matematika dalam penyelesaian masalahnya. Pada penelitian ini, konteks-konteksnya dibatasi pada hasil pertanian yang mengacu pada hasil penelitian Fatimah \& Solihah (2020). Konteks-konteks tersebut digunakan untuk mengonstruksi tugas matematis.

Selain konteks, tugas matematis tentunya melibatkan konsep-konsep dan prosedur matematis untuk menyelesaikannya. Konstruksi tugas matematis ini juga sejalan dengan standar koneksi matematis (National Council of Teachers of Mathematics, 2000). Oleh karena itu, penelitian memiliki fokus terhadap koneksi matematis pada konstruksi tugas matematis berbasis hasil pertanian dan kemampuan koneksi matematis siswa SMK dalam menyelesaikan tugas matematis tersebut. 


\section{Metode}

Penelitian ini menggunakan pendekatan kualitatif dengan metode studi kasus tipe deskriptif (Hancock \& Algozzine, 2006). Metode ini dipilih karena kasus yang diteliti bersifat khas yaitu koneksi matematis yang melibatkan konteks hasil pertanian. Studi kasus ini mendeskripsikan kekhasan dalam mengonstruksi tugas matematis berbasis hasil pertanian dan kemampuan koneksi siswa dalam menyelesaikan tugas dengan menitikberatkan pada koneksi konteks dengan konsep matematis, koneksi antar konsep matematis, dan koneksi prosedur matematis.

Konstruksi tugas matematis sejalan dengan penelitian yang dilakukan oleh Siswono, (2015) yang menyatakan bahwa desain tugas harus sesuai dan memenuhi kriteria suatu kemampuan matematis baik dari aspek isi, tingkat kemampuan, konteks dan bentuk tugas. Pada aspek isi (materi), tugas matematis ini dikonstruksi berdasarkan konsep bilangan bentuk pangkat. Dari aspek tingkat kemampuan, konstruksi tugas matematis n mengacu pada strandar koneksi matematis berdasarkan National Council of Teachers of Mathematics (2000), yaitu: mengenali dan menggunakan koneksi di antara ide matematis, memahami bagaimana ide-ide matematis saling berhubungan dan membangun untuk menghasilkan keseluruhan yang koheren, serta mengenali dan menerapkan matematika dalam konteks di luar matematika. Berdasarkan aspek konteks, tugas ini mengambil konteks di luar matematika yaitu konteks hasil pertanian. Adapun bentuk tugas adalah word problem.

Konstruksi tugas matematis juga mengacu pada teori rekontekstualisasi yang diusung oleh FitzSimons \& Björklund Boistrup (2017) yaitu rekontekstualisasi eksplisit. Rekontekstualisasi jenis ini dipilih karena proses penyelesaian tugas secara eksplisit menggunakan matematika dari awal sampai akhir penyelesaian tugas. Rekontekstualisasi ini melibatkan konteks pertanian, konsep bilangan bentuk akar, konsep-konsep matematika yang sering digunakan dalam produksi pengolahan hasil pertanian, serta prosedur-prosedur matematis yang dapat mendorong siswa untuk melakukan prosedur matematis secara tepat dan efisien. Hasil konstruksi tugas matematis kemudian dilihat validitasnya yang terdiri dari validitas konstruk dan konten (Cohen et al. 2007; Siswono, 2015). Validitas kontruks melibatkan dua orang guru SMK Agribisnis Pengolahan Hasil Pertanian yang mengajar kompetensi keahlian C3. Validitas ini dilakukan untuk melihat kesesuaian konteks atau situasi pada tugas dengan realitas konteks hasil pertanian baik secara teoritis maupun praktis. Tugas matematis dikatakan valid jika validator memberi komentar bahwa konteks pada situasi tugas sesuai dengan konteks hasil pertanian. Validator menyatakan bahwa situasi soal sesuai dengan konteks hasil pertanian namun perlu diperbaiki pada tugas nomor tiga. Tugas ketiga awalnya 
menggunakan kontek satuan bata sebagai satuan luas dan disarankan untuk diganti menjadi hektar dengan pertimbangan bahwa tidak semua siswa mengenal satuan tradisional. Oleh karena itu, satuan diubah menjadi hektar.

Validitas konten a dilakukan dengan melibatkan dua orang guru matematika SMK Agribisnis Pengolahan Hasil Pertanian untuk melihat kesesuaian KI dan KD mata pelajaran matematika yang membentuk tugas matematis. Tugas matematika dkatakan valid dari segi konten jika siuasi tugas sesuai dengan ada pada KI dan KD mata pelajaran Matematika kelas $\mathrm{X}$. Validator guru matematika memberikan komentar bahwa situasi tugas masuk pada KI dan KD 3.1, tugas akan mendukung keterampilan siswa dalam mengaplikasikan sifat-sifat bilangan bentuk pangkat, dan dapat memeberikan wawasan yang lebih terutama bentuk bilangan pangkat dalam notasi ilmiah. Selain itu, validitas juga melibatkan ahli pendidikan matematika yang pernah terlibat dalam penelitian koneksi matematis. Tugas dikatakan valid apabila tugas sesuai dengan indikator kemampuan koneksi matematis. Validator memberi komentar bahwa isi tugas sesuai denga koneksi matematis yang menitikberatkan pada konteks, konsep, dan prosedur matematis yang saling terkoneksi untuk mencapai penyelesaian.

Reliabilitas tes dilakukan untuk melihat bagaimana konteks tugas yang disajikan mempengaruhi kinerja siswa dalam menyelesaikan tugas. Reliabitas ini tidak diukur secara numerik karena kemampuan koneksi matematis pada penelitian ini tidak dideskripsikan dalam bentuk numerik. Reliabilitas yang dilakukan untuk melihat tingkat keterbacaan tugas matematis pada aspek konteks, konsep, dan prosedur matematis. Tiga orang siswa SMK Agribisnis Pengolahan Hasil Pertanian yang pernah belajar bilangan bentuk pangkat terlibat dalam pengujian ini. Hasilnya menunjukkan bahwa siswa mengenali istilah-istialh pada situasi tugas seperti hasil panen, besaran dan satuan, bentuk pangkat, persentase, luas, dan penyusutan.

Setelah tugas dinyatakan valid dan reliabel, tugas digunakan untuk mengetahui kemampuan koneksi matematis dan diberikan kepada siswa SMK Agribisnis Pengolahan Hasil Pertanian. Siswa yang terlibat dalam penelitian ini adalah satu kelas yaitu kelas $\mathrm{X}$ sebanyak 13 orang (5 laki-laki dan 8 perempuan) yaitu S1, S2, S3, .., S13. Selama proses penyelesaian tugas berlangsung, peneliti dan guru matematika melakukan observasi untuk melihat respons siswa terhadap tugas yang diberikan sehingga diperoleh klasifikasi kasuskasus kemampuan koneksi matematis yang bersifat khas untuk diperdalam dalam proses wawancara. Oleh karena itu, wawancara hanya melibatkan perwakilan dari tiap-tiap kasus yang ditemukan. Wawancara dilakukan setelah observasi dan menganalisis lembar jawaban 
siswa. Wawancara terhadap siswa ini berfokus pada aspek koneksi konteks, konsep, dan prosedur matematis.

Hasil jawaban, observasi, dan wawancara di analisis untuk melihat kemampuan koneksi matematis siswa yang berfokus pada koneksi konteks dengan konsep matematis, koneksi antar konsep matematis, dan koneksi prosedural matematis. Konteks merupakan masalah yang disajikan pada tugas matematis dalam situasi hasil pertanian. Konsep-konsep yang disajikan pada tugas matematis dalam penelitian ini meliputi bentuk pangkat yang dikoneksikan dengan konsep-konsep yang sering digunakan dalam hasil pertanian. Prosedur matematis adalah tahapan penyelesaian tugas sehingga diperoleh jawaban yang masuk akal. Tabel 1 berikut menyajikan indikator koneksi matematis pada tugas matematis berbasis konteks hasil pertanian.

Tabel 1. Indikator Kemampuan Koneksi Matematis pada Tugas Matematis

\begin{tabular}{llll}
\hline \multicolumn{1}{c}{ Indikator } & \multicolumn{3}{c}{ Deskripsi } \\
\hline $\begin{array}{l}\text { Koneksi konteks } \\
\text { dengan konsep }\end{array}$ & $\begin{array}{l}\text { Mampu merepresentasikan bahasa/kalimat yang terdapat pada } \\
\text { konteks tugas ke dalam suatu simbol atau model matematika } \\
\text { (misalnya fungsi, persamaan, pertidaksamaan, dll.) }\end{array}$ \\
\hline $\begin{array}{l}\text { Koneksi antar } \\
\text { konsep matematis }\end{array}$ & $\begin{array}{l}\text { Mampu menghubungkan konsep-konsep matematis untuk } \\
\text { mendukung penyelesaian tugas. }\end{array}$ & \\
\hline Koneksi antar & Mampu menunjukkan tahapan dan hubungan prosedur matematis \\
prosedur matematis & sehingga diperoleh jawaban yang masuk akal. & \\
\hline
\end{tabular}

Validasi hasil penelitian ini ditunjukkan melalui triangulasi data, verifikasi terhadap guru matematika, teori-teori dan penelitian sebelumnya. Data kemampuan koneksi matematis siswa dikumpulkan melalui tiga cara yaitu observasi, wawancara, dan lembar jawaban siswa. Verifikasi terhadap hasil analisis dilakukan terhadap guru matematika sebagai orang yang mengetahui lebih dalam kemampuan matematis siswa. Hasil penelitian juga diverifikasi melalui hasil-hasil penelitian sebelumnya yang memmiliki relevansi dengan penelitian ini.

\section{Hasil Penelitian}

Hasil penelitian ini terdiri dari dua bagian yaitu mendeskripsikan konstruksi tugas matematis berbasis hasil pertanian dan kemampuan koneksi matematis siswa SMK dalam menyelesaikan tugas matematis berbasis hasil pertanian.

\section{Tugas Matematis Berbasis Hasil Pertanian}

Mengonstruksi tugas matematis berbasis pengolahan hasil pertanian artinya membawa konteks hasil pertanian kepada matematika formal yang dipelajari di SMK. Konteks-konteks pengolahan hasil pertanian dalam tulisan ini mengacu pada hasil penelitian Fatimah \& Solihah (2020). Pengolahan hasil pertanian yang terdapat di SMK Agribisnis Pengolahan 
Hasil Pertanian terdiri dari aspek pengolahan hasil nabati, hewani, perkebunan, dan herbal. Adapun peran matematika pada aspek tersebut terdapat pada konteks perhitungan alat, bahan, dan proses pengolahan hasil pertanian, pengemasan, serta analisis usaha. Pada tulisan ini, konteks pengolahan hasil pertanian dibatasi pada konteks hasil pertanian nabati.

Konteks-konteks pada hasil pertanian tersebut digunakan untuk mengonstruksi tugas matematis melalui suatu rekontekstualisasi. Rekontekstualisasi matematika pada tugas matematis ini mempertimbangkan model-model yang diusung oleh FitzSimons \& Björklund Boistrup (2017). Terdapat empat model tugas matematis yang diperkenalkannya yaitu tipe A (matematika tanpa konteks kejuruan), B (penggunaan eksplisit dari model matematika atau konsep lainnya sebelum, selama dan setelah kegiatan kerja), C (konsep dan metode matematika atau konsep lainnya terintegrasi secara implisit ke dalam kegiatan kerja), dan D (kegiatan kejuruan tanpa matematika). Rekontekstualisasi matematika pada tugas matematis berbasis pengolahan hasil pertanian ini merupakan model tipe B.

Melalui model rekontekstualisasi ini, pengoneksian dilakukan antara konteks-konteks pengolahan hasil pertanian dengan kompetensi dasar "Menyajikan penyelesaian masalah bilangan berpangkat, bentuk akar dan logaritma". Kompetensi dasar ini untuk siswa SMK Kelas X Semester pertama. Pada tulisan ini, konstruksi tugas matematis dibatasi pada ruang lingkup materi bilangan bentuk pangkat. Oleh karena itu, konsep matematis yang utama muncul pada setiap tugas adalah konsep bilangan bentuk pangkat dengan melibatkan konsep matematis lainnya yang bermanfaat dalam penyelesaian masalah di bidang produksi pengolahan hasil pertanian.

Terdapat tiga tugas matematis yang dikonstruksi dan diberikan kepada siswa untuk mengetahui kemampuan koneksi matematis. Tugas tersebut menitikberatkan pada konteks, konsep, dan prosedur matematis. Perhatikan Tabel 2. Konteks tugas yang disajikan pada tugas pertama adalah hasil panen buah mangatugas kedua memiliki konteks hasil penen buah pisang, dan tugas ketiga memiliki konteks hasil pertanian umbi-umbian. Adapun konsep matematis yang dibutuhkan oleh siswa untuk mendapatkan solusi pada tugas pertama adalah merepresentasikan bilangan desimal ke dalam bilangan bentuk pangkat. Namun demkian, untuk mendapatkan solusi yang tepat, diperlukan terlebih dahulu kemampuan mengonversi satuan ton ke dalam satuan gram. Pada tugas kedua, siswa dapat merepresentasikan bilangan bentuk pangkat ke dalam bentuk bilangan desimal terlebih dahulu atau dapat juga langsung menggunakan bentuk pangkat tersebut dengan penguasaan sifat-sifat bilangan bentuk pangkat. Tugas ketiga secara konseptual sejalan dengan tugas pertama yaitu berhubungan 
dengan representasi bilangan dalam bentuk pangkat, namun situasinya lebih rumit lagi. Pada tugas ketiga ini, diperlukan beberapa koneksi antar konsep dan prosedur matematis.

Ketiga tugas memiliki prosedur penyelesaian yang berbeda namun memiliki kekhasan untuk menanamkan konsep konversi satuan. Keterampilan konversi satuan bagi siswa SMK Agribisnis Pengolahan Hasil pertanian ini merupakan keterampilan yang penting karena dalam suatu produksi pengolahan hasil pertanian banyak menggunakan besaran-besaran dengan beragam satuan (Fatimah \& Solihah, 2020). Pengetahuan tentang prosedur mengubah bentuk bilangan desimal ke pangkat dan sebaliknya juga menjadi hal yang penting pada penyelesaian tugas. Secara khusus, pada tugas kedua, pengetahuan tentang prosedur operasi bilangan pecahan desimal menjadi penentu keberhasilan penyelesan tugas ini. Semua tugas yang disajikan menuntun siswa untuk menggunakan prosedur yang tepar, fleksibel, akurat, dan efisien seperti yang telah dikemukakan oleh Kilpatrick et al (2001).

Tabel 2. Tugas Matematis Berbasis Konteks Pengolahan Hasil Nabati

\begin{tabular}{|c|c|}
\hline Tugas & Deskripsi \\
\hline Tugas 1 & $\begin{array}{l}\text { Seorang petani mendapatkan hasil panen mangga sebanyak } 17 \text { ton. } \\
\text { Nyatakan berat mangga hasil panen tersebut dalam satuan gram dan } \\
\text { nyatakan bilangan tersebut dalam bentuk notasi ilmiah. }\end{array}$ \\
\hline Tugas 2 & $\begin{array}{l}\text { Seorang petani mendapatkan hasil panen pisang sebanyak } 10^{7} \mathrm{~kg} \text {. Berat } \\
\text { pisang mengalami penyusutan } 15 \% \text { setelah } 10 \text { hari. Tentukan berat } \\
\text { pisang setelah mengalami penyusutan. }\end{array}$ \\
\hline Tugas 3 & $\begin{array}{l}\text { Dalam satu hektar singkong terdapat } 10.000 \text { pohon singkong gajah. } \\
\text { Rata-rata satu pohon singkong menghasilkan } 20 \mathrm{~kg} \text {. seorang petani } \\
\text { memiliki lahan seluas } 5 \text { hektar. Jika budidaya singkong tersebut berjalan } \\
\text { lancar, berapa ton singkong yang dihasilkan petani. Tulislah dalam } \\
\text { bentuk notasi ilmiah. }\end{array}$ \\
\hline
\end{tabular}

Konstruksi tugas matematis pada Tabel 2 ini memenuhi tiga standar koneksi matematis National Council of Teachers of Mathematics (2000) karena situasi tugas tersebut berusaha untuk mengenalkan dan menerapkan matematika pada konteks hasil pertanian. Tugas ini juga bersaha mengenalkan dan menggunakan koneksi antar ide matematis yang berhubungan dengan ide-ide matematis yang biasa digunakan di dalam kompetensi agribisnis pengolahan hasil pertanian, seperti keterampilan konversi satuan dan konversi bentuk bilangan. Situasi tugas yang disajikan dalam bentuk word ploblem menuntun siswa untuk memahami bagaimana ide-ide matematis saling berhubungan dan membangun untuk menghasilkan keseluruhan yang koheren. 
S3 : "Saya bingung membuat bentuk pangkat karena didepannya bilangan 17".

S5 : "Saya membuat 1.700 .000 menjadi 17 kali 100.000. Kemudian saya ubah 100.000 menjadi bentuk pangkat. Tapi saya tidak teliti jadi salah mengubah ton ke kilogram, tertukar sama kuwintal".

S7 : "Saya bingung karena bilangannya tidak dapat dibuat pangkat. Kemudian saya pisahkan bilangan yang bias dibuat pangkat. Bilangan tersebut menjadi $17 \times 10^{6}$.

Hasil analisis lembar jawaban pada tugas kedua menunjukkan bahwa sembilan orang siswa (S1, S2, S3, S5, S6, S7, S8, S12, S13) dapat menyelesaikan tugas dengan benar. Dua orang siswa (S4, S9) hanya mengerjakan sampi berat penyusutannya saja dan dua orang (S10, S11) lagi hanya merepresentasikan bentuk pangkat pada bentuk desimal. Hasil analisis tersebut menunjukkan bahwa sebagian besar siswa memiliki kemampuan koneksi konteks dan konsep, koneksi antar konsep matematis, dan koneksi antar prosedur matematis. Sebagian siswa yang belum menyelesaikan tugas kedua dengan benar terkendala pada kemampuan koneksi antar konsep matematis. Gambar 2 berikut merupakan contoh respons siswa terhadap tugas 2 .

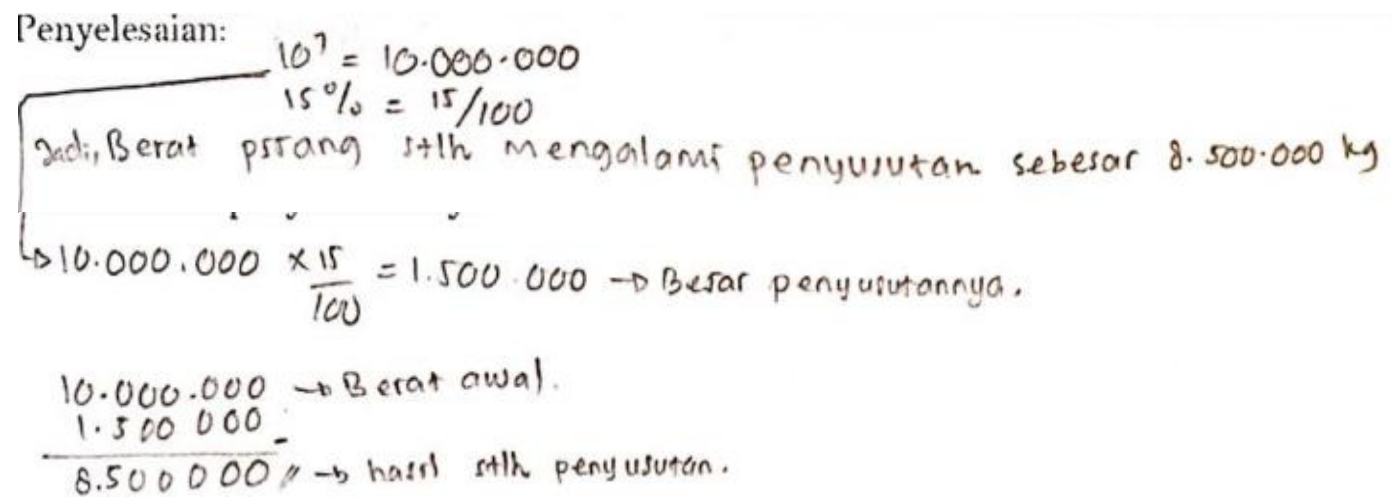

Gambar 2. Contoh Respons Siswa pada Tugas 2

Hasil wawancara terhadap siswa yang belum dapat menyelesaikan tugas kedua menyatakan bahwa siswa kebingungan dengan konsep penyusutan. Berikut adaalah hasil wawancaranya:

S9 : "Saya bisa menghitung banyaknya penyusutan, caranya dikalikan saja hasil panen dengan persen. Tapi saya tidak tahu caranya menghitung sisa penyusutannya".

S11 : "Saya tidak tahu cara menghitung penyusutan. Saya hanya bisa mengubah $10^{7}$ menjadi 10.000.000".

Hasil analisis pada tugas ketiga menunjukkan bahwa hanya dua orang siswa (S12, S13) yang dapat menyelesaikan tugasnya dengan benar sedangkan sebelas siswa lainnya memiliki kesalahan yang beragam. Kesalahan terjadi dalam melakukan konversi satuan dan atau prosesur matematis. Secara keseluruhan, siswa dapat mengoneksikan konteks hasil pertanian 
ke dalam konsep matematis. Gambar 3 berikut merupakan contoh respons siswa terhadap tugas ketiga.
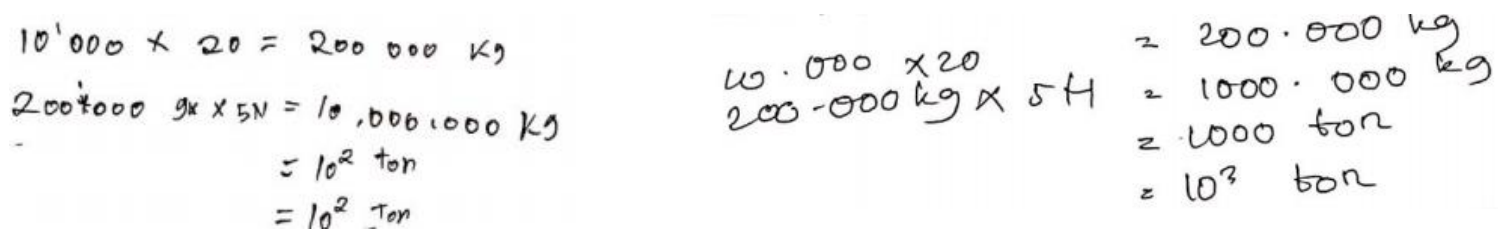

Gambar 3. Contoh Dua kasus Respons Siswa pada Tugas 3

Hasil wawancara menunjukkan bahwa siswa mengetahui konteks yang dimasud pada tugas adalah bentuk pangkat. Kegagalan diakibatkan oleh kurangnya kemampuan siswa dalam melakukan prosedur matematis. Berikut merupakan kutipan hasil wawancaranya:

S1 : "Setelah saya pikir, kesalahan saya dalam proses perkalian berat singkong dengan luas lahan".

S4 : "Saya kalikan 10.000 dengan lima hektar, kemudian saya kalikan berat singkong dengan hektar".

S6 : "Saya kurang teliti ketika mengubah bilangan ke bentuk pangkat".

\section{Pembahasan}

Kemampuan siswa dalam mengenali dan menerapkan matematika dalam konteks di luar matematika merupakan salah satu standar koneksi matematis pada National Council of Teachers of Mathematics (2000). Konteks di luar matematika pada penelitian ini adalah hasil pertanian. Konteks-konteks tersebut merupakan objek pengetahuan kejuruan dan guru matematika perlu lebih mengenal objek pengetahuan kejuruan tersebut (FitzSimons, 2014). Oleh karena itu, upaya memunculkan konteks-konteks yang sesuai dengan bidang keahlian siswa merupakan suatu upaya mengoneksikan matematika pada konteks di luar matematika.

Kemampuan koneksi matematis siswa SMK sejalan dengan peraturan menteri pendidikan dan kebudayaan nomor 34 Tahun 2018 tentang standar isi. Standar matematika tersebut menuntun siswa SMK mampu berpikir matematis yang berkaitan dengan bidang kerjanya yang dapat dilakukan dengan menggunakan pengetahuan faktual, konseptual dan prosedural matematis. Hasil analisis kemampuan koneksi matematis siswa menunjukkan bahwa siwa memiliki kemampuan faktual yang dicirikan dengan kemampuan mengidentifikasi dan memahami konteks-konteks hasil pertanian. Secara konseptual dan prosedural, sebagian siswa telah mampu mengoneksikan beberapa konsep matematis dan melakukan operasi matematis, sedangkan sebagian lagi memiliki kendala yang beragam baik dari segi konseptual maupun prosedural matematis.

Kendala-kendala siswa pada fase konseptual cenderung diakibatkan pada ketidaksiapan siswa menggunakan konsep-konsep matematis yang beragam secara bersama-sama dalam 
satu konteks permasalahn untuk mencapai solusi. Hal ini terungkap dari fakta bahwa siswa mengetahui konsep pangkat, mengetahui konsep bilangan dalam bentuk persen, mengetahui sistem konversi, dan lain sebagainya. Kendala-kendala tersebut tentunya dapat diatasi dengan pembiasaan memberikan tugas matematis yang melibatkan konsep beragam.

Kemampuan koneksi matematis pada suatu konteks jelas penting bagi siswa. Hasil penelitian mengungkapkan bahwa siswa menganggap proses mengoneksikan matematika dengan kehidupan nyata itu penting, namun mereka merasa bahwa proses ini tidak dilaksanakan secara memadai (Baki et al., 2009). Hal ini memberi konsekuensi terhadap guru untuk senantiasa melakukan rekontektualisasi matematika terhadap suatu konteks sehingga siswa memiliki kemampuan koneksi yang baik yang mendukung penyelesaian masalah di dunia nyata.

Selain konteks, desain tugas matematis juga berkaitan dengan tujuan penggunaan tugas (Johnson et al., 2017), sifat tugas (Yeo, 2017), dan kemampuan matematis yang akan dikembangkan pada siswa (Lithner, 2017). Desain tugas pada Tabel 1 dapat digunakan dalam beragam tujuan, misalnya untuk mengenalkan konsep bilangan berpangkat, sebagai soal latihan, atau untuk memberi kesempatan kepada siswa untuk menyelesaikan suatu prosedur matematis dalam situasi beragam. Situasi-situasi dalam konteks beragam akan mengantarkan siswa pada proses berpikir matematis yang kreatif dalam menyelesaikan tugas yang diberikan.

Tugas matematis yang dikonstruksi pada penelitian ini cenderung fokus pada topik bilangan. Hal ini selaras dengan hasil penelitian Fatimah \& Solihah (2020) yang menyatakan bahwa konten bilangan dominan memiliki peran dalam mata pelajaran keahlian agribisnis pengolahan hasil pertanian. Jika dilihat lagi pada hasil analisis lembar jawaba siswa, koneksi antar konsep matematika merupakan koneksi beberapa konsep bilangan. Kemampuan koneksi ini tidak lepas dari kemampuan number sense siswa. Slusser (2019) menyatakan bahwa menghitung dan keterampilan dasar bilangan berhubungan dengan number sense.

Hasil penelitian Fatimah \& Wahyudin (2020) menunjukkan bahwa number sense siswa pada penyelesaian tugas seringkali dipengaruhi oleh situasi tugas, pengetahuan dan pengalaman siswa. Kendala siswa pada aspek koneksi antar konsep matematis dan prosedral matematis berdasarkan hasil analisis cenderung diakibatkan oleh situasi soal yang menuntut penggunaan beberapa konsep. Hal ini sejalan dengan hasil penelitian Can \& Özdemir (2019) yaitu siswa cenderung lebih berhasil dalam menyelesaikan tugas tanpa konteks dibandingkan dengan tugas yang memiliki konteks.

Namun demikian, masalah-masalah di tempat kerja tentunya selalu berhubungan dengan konteks. Hal ini memberikan konsekuensi terhadap guru matematika yang mengajar 
di SMK untuk mempersiapkan bahan ajar matematika yang terkait dengan tempat kerja. Temuan penelitian menunjukkan bahwa bahan ajar belum menyajikan masalah terkait pekerjaan dengan baik sehingga siswa tidak memiliki persiapan yang memadai terkait dengan pengalaman dalam masalah terkait pekerjaan (Shahrill, 2014). Guru matematika seyogyanya merumuskan matematika baik dari segi konseptual maupun kontekstual dengan mempertimbangkan penggunaan matematika dalam praktik sehingga terwujud suatu artefak yang mendukung pengembangan komunitas praktik (Wake, 2014).

Tentunya gagasan tentang keterpaduan antara matematika di luar dan di dalam sekolah merupakan hal ideal di sekolah kejuruan (Swanson \& Williams, 2014). Gagasan tersebut untuk mengembangkan kemampuan konseptual matematis siswa yang dibutuhkan dalam pemecahan masalah di tempat kerja (FitzSimons \& Björklund Boistrup, 2017). Pengembangan kemampuan pemahaman konseptual matematis tersebut merupakan salah satu upaya membekali siswa untuk memiliki kemampuan berpikir matematis terhadap konteks keahlian kejuruan seperti yang tercantum pada standar kelulusan yaitu siswa memiliki kemampuan pemahaman matematis sesuai dengan keahliannya.

\section{Simpulan}

Tugas matematis berbasis hasil pertanian merupakan tugas matematis yang dikonstruksi untuk siswa SMK jurusan pertanian, khususnya siswa agribisnis pengolahan hasil pertanian. Tugas matematis ini mengoneksikan konsep matematika pada konteks-konteks hasil pertanian. Kekhasan dari tugas matematis ini adalah mengintegrasikan konsep bilangan bentuk pangkat dan konsep-konsep matematis yang berperan dalam mata pelajaran keahlian agribisnis pengolahan hasil pertanian. Tugas matematis ini mengupayakan pembiasaan koneksi matematis siswa SMK agribisnis pengolahan hasil pertanian untuk melakukan koneksi konteks hasil pertanian dengan konsep matematis, melakukan koneksi antar konsep matematis, dan melakukan beragam prosedur matematis.

Sebagian besar siswa sudah memiliki kemampuan koneksi konteks dengan konsep matematis. Hal ini tidak terlepas dari situasi tugas yang dikenali oleh peserta didik. Kendala yang paling banyak terjadi pada siswa adalah kemampuan koneksi antar konsep dan prosedur matematis. Hasil penelitian ini menuntun upaya untuk terus dilakukannya pengembangan kemampuan koneksi matematis siswa untuk mempersiapkan siswa menyelesaikan beragam masalah di bidang pertanian yang melibatkan matematika di dalamnya. 


\section{Referensi}

Baki, A., Çatlioğlu, H., Coştu, S., \& Birgin, O. (2009). Conceptions of high school students about mathematical connections to the real-life. Procedia - Social and Behavioral Sciences, 1(1), 1402-1407. https://doi.org/10.1016/j.sbspro.2009.01.247.

Bakker, A. (2014). Characterising and developing vocational mathematical knowledge. Educational Studies in Mathematics, 86(2), 151-156. https://doi.org/10.1007/s10649014-9560-4.

Bernstein, B. (2000). Pedagogy, symbolic control and identity: Theory, research, critique (Rev. ed.). Rowman \& Littlefield.

Can, D., \& Özdemir, İ. E. Y. (2019). An examination of fourth-grade elementary school students' number sense in context-based and non-context-based problems. International Journal of Science and Mathematics Education, 18, 1333-1354. https://doi.org/10.1007/s10763-019-10022-3.

Chang, Y. P., Krawitz, J., Schukajlow, S., \& Yang, K. L. (2020). Comparing German and Taiwanese secondary school students' knowledge in solving mathematical modelling tasks requiring their assumptions. ZDM - Mathematics Education, 52(1), 59-72. https://doi.org/10.1007/s11858-019-01090-4.

Cohen, L., Manion, L., \& Morrison, K. (2007). Research methods in education (R. T. \& F. Group (ed.)). https://doi.org/10.4324/9780203029053.

Fatimah, A. T., \& Prabawanto, S. (2020). Mathematical understanding and reasoning of vocational school students in agriculture-based mathematical tasks. Journal for the Education of Gifted Young Scientists, 8(2), 701-712. https://doi.org/10.17478/jegys.702884.

Fatimah, A. T., Pramuditya, S. A., \& Wahyudin, W. (2019). Imitative and creative reasoning for mathematical problem solving (in context horticultural agribusiness). Journal of Physics: Conference Series, 1157(4). $\quad$ https://doi.org/10.1088/17426596/1157/4/042092.

Fatimah, A. T., \& Solihah, S. (2020). Matematika pada mata pelajaran produksi pengolahan hasil pertanian. Jumlahku Jurnal Matematika Ilmiah, 6(2), 176-187. https://doi.org/10.33222/jumlahku.v6i2.1118.

Fatimah, A. T., \& Wahyudin, W. (2020). Number sense siswa SMK pada tugas matematis berbasis pertanian. Teorema: Teori dan Riset Matematika, 5(2), 133. https://doi.org/10.25157/teorema.v5i2.3322.

Fatimah, A. T., Wahyudin, W., \& Prabawanto, S. (2020). The role of agricultural contextual knowledge on the mathematical understanding of vocational students. Journal of Physics: Conference Series, 1521(3). $\quad$ https://doi.org/10.1088/17426596/1521/3/032020.

FitzSimons, G. E. (2014). Commentary on vocational mathematics education: Where mathematics education confronts the realities of people's work. Educational Studies in Mathematics, 86(2), 291-305. https://doi.org/10.1007/s10649-014-9556-0.

FitzSimons, G. E., \& Björklund Boistrup, L. (2017). In the workplace mathematics does not announce itself: towards overcoming the hiatus between mathematics education and work. Educational Studies in Mathematics, 95(3), 329-349. https://doi.org/10.1007/s10649-017-9752-9.

Gronow, M., Mulligan, J., \& Cavanagh, M. (2020). Teachers' understanding and use of mathematical structure. Mathematics Education Research Journal. https://doi.org/10.1007/s13394-020-00342-x

Hamami, Y., Lea, R., \& Morris, R. L. (2020). Philosophy of mathematical practice : a primer for mathematics educators. ZDM, 52, 1113-1126. https://doi.org/10.1007/s11858-02001159-5. 
Hancock, D. R., \& Algozzine, B. (2006). Doing case study research: A practical guide for beginning researchers. In Teachers College Press. https://doi.org/10.1353/csd.2007.0003.

Johnson, H. L., Coles, A., \& Clarke, D. (2017). Mathematical tasks and the student: navigating "tensions of intentions" between designers, teachers, and students. ZDM Mathematics Education, 49(6), 813-822. https://doi.org/10.1007/s11858-017-0894-0.

Kilpatrick, J. , Swafford, J., Findell, B. (2001). Adding It Up-Helping Children Learn Mathematics. National Academy Press.

Kinser-Traut, J. Y., \& Turner, E. E. (2020). Shared authority in the mathematics classroom: successes and challenges throughout one teacher's trajectory implementing ambitious practices. Journal of Mathematics Teacher Education, 23(1), 5-34. https://doi.org/10.1007/s10857-018-9410-x.

Lacroix, L. (2014). Learning to see pipes mathematically: preapprentices' mathematical activity in pipe trades training. Educational Studies in Mathematics. https://doi.org/10.1007/s10649-014-9534-6.

Lin, F. L., Yang, K. L., Hsu, H. Y., \& Chen, J. C. (2018). Mathematics teacher educatorresearchers' perspectives on the use of theory in facilitating teacher growth. Educational Studies in Mathematics, 98(2), 197-214. https://doi.org/10.1007/s10649018-9804-9.

Lithner, J. (2017). Principles for designing mathematical tasks that enhance imitative and creative reasoning. ZDM - Mathematics Education, 49(6), 937-949. https://doi.org/10.1007/s11858-017-0867-3.

Llinares, S. (2020). Promoting explicit connections in mathematics teaching: scopes for the teachers learning in context. Journal of Mathematics Teacher Education, 23(1), 1-4. https://doi.org/10.1007/s10857-020-09455-3.

National Council of Teachers of Mathematics. (2000). Principle and standards for school mathematics. The NCTM.

Pongsakdi, N., Kajamies, A., Veermans, K., Lertola, K., Vauras, M., \& Lehtinen, E. (2020). What makes mathematical word problem solving challenging? Exploring the roles of word problem characteristics, text comprehension, and arithmetic skills. ZDM Mathematics Education, 52(1), 33-44. https://doi.org/10.1007/s11858-019-01118-9.

Shahrill, M. (2014). Mathematics in Vocational and technical education: Investigating the relationship in engineering work related problems. July, 3282-3292.

Siswono, T. Y. E. (2015). Desain tugas untuk mengidentifikasi kemampuan berpikir kreatif siswa dalam matematika. 1-14.

Slusser, E. (2019). Counting and basic numerical skills. International Handbook of Mathematics Learning Difficulties, 521-542. https://doi.org/10.1007/978-3-319-971483_31.

Swanson, D., \& Williams, J. (2014). Making abstract mathematics concrete in and out of school. Educational Studies in Mathematics, 86(2), 193-209. https://doi.org/10.1007/s10649-014-9536-4.

Wake, G. (2014). Making sense of and with mathematics: The interface between academic mathematics and mathematics in practice. Educational Studies in Mathematics, 86(2), 271-290. https://doi.org/10.1007/s10649-014-9540-8.

Williams, J., \& Wake, G. (2007). Black boxes in workplace mathematics. Educational Studies in Mathematics, 64(3), 317-343. https://doi.org/10.1007/s10649-006-9039-z.

Yeo, J. B. W. (2017). Development of a framework to characterise the openness of mathematical tasks. International Journal of Science and Mathematics Education, 15(1), 175-191. https://doi.org/10.1007/s10763-015-9675-9. 